http://dx.doi.org/10.15762/ZH.2015.42

\author{
TOMASZ KRZEMINSSKI \\ (Instytut Historii PAN)
}

\title{
ODBIÓR SPOŁECZNY KINEMATOGRAFII NA POMORZU NADWIŚLAŃSKIM W POCZĄTKACH XX WIEKU
}

Słowa kluczowe: życie codzienne, Prusy Zachodnie, województwo pomorskie, rozrywka, uczestnictwo w kulturze, historia mediów, kino, mentalność, obyczajowość, czas wolny

Krótkie, acz dynamiczne dzieje kin i odbioru sztuki filmowej w miastach pomorskich doczekały się niewielu studiów monograficznych. Prace te obrazują rozwój i wzrost popularności nowej formy rozrywki w największych ośrodkach miejskich regionu: Gdańsku, Toruniu, Elblągu czy Gdyni ${ }^{1}$. Omówione w nich zostały dzieje poszczególnych kin i opisano repertuar filmowy pomorskich iluzjonów. Poruszona także została niezwykle interesująca kwestia recepcji nowego medium przez społeczeństwo regionu w zmiennych warunkach politycznych pierwszej połowy XX w. Zagadnienie to wydaje się ciekawym i wciąż otwartym problemem badawczym przede wszystkim w odniesieniu do oddziaływania na mentalność i obyczajowość mieszkańców Pomorza w burzliwych latach tej epoki.

Upowszechnienie fotografii w drugiej połowie XIX w. zintensyfikowało działania zmierzające do utrwalenia i edycji obrazu ruchomego. Prace w tym kierunku prowadzone przez wielu niezależnych wynalazców zwieńczone zostały w roku 1895 skonstruowaniem urządzeń umożliwiających zapis i odtworzenie ruchu. Swoisty wyścig i rywalizację wygrali bracia August i Louis Lumière, którzy jako pierwsi opatentowali kinematograf i w pełni wykorzystali jego możliwości marketingowe ${ }^{2}$. Początkowo wynalazek traktowano jako kawiarnianą rozrywkę, jednak już kilka lat po pierwszym pokazie wzrósł poziom artyzmu produkcji filmowych,

${ }^{1}$ Marek Andrzejewski, Z dziejów kina w Gdańsku w latach 1896-1945, Gdańsk 2013; idem, Rozwój kina w Elblagu w latach 1918-1945, Rocznik Elbląski, t. 20: 2006, s. 7-13; Katarzyna KLuczwajD, Toruńskie teatry świetlne, czyli kina, wytwórczość filmowa i miejscowe gwiazdy 1896-1939. O kulturze czasu wolnego dawnych torunian, Toruń 2013; Patrycja ŚLIwIŃsKa, Kina międzywojennej Gdyni, [in:] Wędrówki po dziejach Gdyni. Zbiór studiów, red. Dagmara PŁaza-Opacka, Tadeusz Stegner, Gdynia 2004, s. 83-118.

${ }^{2}$ Małgorzata Hendryкowska, 1896 Cinematografe - kamera braci Lumière, [in:] Historia kina. Wybrane lata, red. Andrzej KoŁodyński, Konrad J. ZaręBSKI, Warszawa 1998, s. 8; Jürgen OsterHAMmel, Historia XIX wieku. Przeobrażenie świata, tłum. Izabela DrozdowskA-Broering, Poznań 2013, s. 68. 
a kinematografia stała się jedną z ulubionych form spędzania wolnego czasu wśród ludności wszelkiej kondycji społecznej. Z początkiem XX stulecia nawet w niewielkich miasteczkach Europy, a przede wszystkim Ameryki Północnej tworzono sale pokazowe przeznaczone wyłącznie do wyświetlania filmów. W Stanach Zjednoczonych zyskały one nazwę "nickelodeonów” ze względu na fakt, że wstęp na seans kosztował zaledwie kilka centów (monet wykonanych z niklu). I właśnie stosunkowa taniość nowego medium sprawiała, że w zdumiewająco szybkim tempie zdobyło ono ogromną popularność, co z kolei przełożyło się na dochodowość produkcji i przedsiębiorstw kinowych.

Pomorze Nadwiślańskie stanowiące część Królestwa Prus i dynamicznie rozwijającej się cywilizacyjnie Rzeszy Niemieckiej mimo peryferyjnego położenia nie pozostawało $\mathrm{w}$ tyle $\mathrm{w}$ pogoni za najświeższymi nowinkami w dziedzinie masowej rozrywki. Zaledwie w kilkanaście miesięcy po paryskiej premierze mieszkańcy Gdańska, a wkrótce także innych miejscowości tej nadbałtyckiej prowincji mogli podziwiać pokazy ruchomych obrazów.

Pierwszy seans filmowy na obszarze Pomorza Nadwiślańskiego odbył się w Gdańsku 20 X 1896 r. Wiosną następnego roku widowiska świetlne podziwiali mieszkańcy Torunia. Z początkiem nowego stulecia $\mathrm{z}$ pokazami ruchomych obrazów obcowali już powszechnie mieszkańcy miasteczek prowincjonalnych ${ }^{3}$. W tym okresie przedstawienia filmowe na terenie Prus Zachodnich realizowali przedsiębiorcy zajmujący się wędrowną rozrywką. Pokazy cyrkowe, karuzele lub wędrowne gabinety osobliwości były wówczas popularną formą zapewniania uciech mieszkańcom zarówno większych, jak i mniejszych miast, między którymi nieustannie kursowały różnego rodzaju ekipy wyspecjalizowanych artystów i showmanów ${ }^{4}$. Seanse filmowe były wtedy $\mathrm{z}$ reguły dodatkiem do innych atrakcji. Jednym z pionierów promujących prezentacje filmowe na terenie prowincji był Jean Baeses, cyrkowiec osiadły w Gdańsku, który prezentował ruchome obrazy świetlne w miastach zachodniopruskich na przełomie wieków ${ }^{5}$.

Podczas pierwszego seansu filmowego w Gdańsku, odbytego w sali Teatru Wilhelma przy Długich Ogrodach, zgromadzonej publiczności zaprezentowano obrazy rodzajowe: „scenki z paryskiej ulicy, jazdę na rowerze, przejażdżkę dorożką, jazdę kabrioletem"'. Tego typu tematyka dominowała w początkowej fazie kina,

${ }^{3}$ M. Andrzejewski, $Z$ dziejów, s. 12; K. Kluczwajd, op.cit., s. 74. Dla porównania pierwszy pokaz w Londynie odbył się w kwietniu, w Melbourne, Madrycie i Berlinie w lutym, w Petersburgu w maju, w Nowym Jorku również w maju, a w Buenos Aires i Szanghaju w sierpniu 1896 r., por. M. HENDRYKowsKa, op.cit., s. 8.

${ }^{4}$ W maju 1903 r. „Gazeta Toruńska” w ten sposób reklamowała zabawę ludową z okazji Zielonych Świątek: „Zabawa ludowa. Na placu przy ogrodzie Wiktoryi od I święta Zielonych Świątek do 7 czerwca. Publiczna zabawa dla młodych i starych. Pomiędzy innymi karuzel parowy, panorama, teatr Kasperlego i teatr małpi, budy szczęścia najróżniejszego rodzaju. Losowanie szynków. Kinematograf, walka zapasowa, teatr afrykański, liczne huśtawki itd. itd. Puszczanie olbrzymiego balonu", zob. Gazeta Toruńska (Gazeta Codzienna) (dalej cyt. Gaz. Tor.), nr 121 z 29 V 1903 r.

${ }^{5}$ Por. Jean Baese. Olbrzymi Kinematograf, Gaz. Tor., nr 110 z 14 V 1905 r.

${ }^{6}$ M. ANdrzejewski, $Z$ dziejów, s. 12. 
co jednak nie odbijało się ujemnie na fascynacji nowym wynalazkiem. W pierwszych latach XX w. popularność widowisk świetlnych była już bardzo duża także na Pomorzu. Konstatował to w czerwcu 1904 r. prezydent regencji kwidzyńskiej w piśmie skierowanym do podległych jego zwierzchności landratów, w którym stwierdzał zaobserwowanie licznych przedstawień kinematograficznych odbywających się z okazji jarmarków i targów. Królewski urzędnik zwracał też uwagę na konieczność przestrzegania zasad bezpieczeństwa przy tego typu spektaklach grupujących zawsze znaczną liczbę widzów ${ }^{7}$. W owym czasie, w zależności od lokalnych uwarunkowań, seanse filmowe odbywały się jedynie w zaimprowizowanych w tym celu obiektach. W Toruniu i Chełmnie urządzano je np. w pomieszczeniach bractw strzeleckich. Najczęściej jednak pokazy świetlne odprawiano w salach restauracyjnych lub $\mathrm{w}$ specjalnie rozstawianych namiotach ${ }^{8}$. Problemem technicznym była kwestia dostarczenia energii elektrycznej niezbędnej do obsługi aparatury filmowej. Podczas gdy w większych miastach można było podłączyć ją od istniejących tam sieci energetycznych, w wielu miasteczkach pomorskich możliwość taka wówczas jeszcze nie istniała. Przedsiębiorcy musieli zatem zapewnić dopływ energii wytworzonej w specjalnych agregatach lub napędzanych parą lokomobilach?.

Wzrastająca popularność przedstawień świetlnych doprowadziła wreszcie, wzorem miast niemieckich, do powstawania kin stałych. I w tej dziedzinie prym wiodły największe miasta regionu. Już w 1907 r. (więc zaledwie w cztery lata po powstaniu pierwszego stałego kina w Rzeszy) gdańszczanie mogli uczestniczyć w seansach kina „Passage Theater (Passage Kinematograph)”. W tym samym roku otwarto iluzjony w Elblągu i Toruniu. Obok kin stałych, nawet w miastach, w których takowe funkcjonowały, odbywały się nadal widowiska prowizoryczne, organizowane przez obwoźnych właścicieli aparatów kinematograficznych. W ślad za wielkimi ośrodkami stałe „teatry świetlne” powstawały też w mniejszych miejscowościach ${ }^{10}$. Jeszcze przed 1914 r. przybytki X Muzy działały m.in. w Kwidzynie, Chełmnie, Chełmży, Chojnicach, Golubiu, Grudziądzu czy Wąbrzeźnie. W niektórych miejscowościach funkcjonowało kilka iluzjonów, np. w czwartym co do wielkości i liczby mieszkańców mieście prowincji - Grudziądzu - działały cztery tego typu zakłady ${ }^{11}$. Pod względem technicznym iluzjony umiejscawiano zazwyczaj w istniejących już loka-

${ }^{7}$ Archiwum Państwowe w Toruniu (dalej cyt. APT), Akta miasta Chełmna (dalej cyt. AMChn.), sygn. 1540, prezydent regencji w Kwidzynie do landrata powiatu chełmińskiego, 12 VII $1904 \mathrm{r}$.

${ }^{8}$ Ibid., landrat powiatu chełmińskiego do zarządu policji w Chełmnie, 20 VII 1904 r.; Archiwum Państwowe w Bydgoszczy (dalej cyt. APB), Akta miasta Nowego nad Wisłą (dalej cyt. AMN), sygn. 664, właściciel drogerii Franz Fischer do zarządu policji w Nowem, 28 X 1903 r. Szerzej o miejscach wyświetlania filmów przez właścicieli kin objazdowych zob. K. KLUCzwAJD, op.cit., s. 74.

${ }^{9}$ APT, AMChn., sygn. 1540, landrat powiatu chełmińskiego do zarządu policji w Chełmnie, 20 VII 1904 r.

${ }^{10}$ Por.: Hanna RZĄSKA, Z dziejów kinematografii w Chojnicach do 1946 roku, Zeszyty Chojnickie, nr 29, 2014, s. 116.

${ }^{11}$ Neues Adreßbuch von Graudenz mit Einschluß der Feste Coubiere, des Truppen-Übungsplätzes Gruppe, der Vororte Kl.-Kunterseit und Kl.-Tapen, Graudenz 1913, IV, s. 45. 
lach, które po koniecznych, wymaganych przepisami budowlanymi przeróbkach mogły się stać siedzibami kinematografów. Były to często dawne sale restauracyjne, sklepy lub magazyny charakteryzujące się dużą przestronnością. W Toruniu kino „Metropol” urządzono np. w siedzibie dawnej ujeżdżalni. W czasie przedstawień wciąż wyczuwalny był tam koński zapach, dlatego też w przerwach między seansami obsługa techniczna skrapiała pomieszczenie perfumami ${ }^{12}$.

Popularność, jaką cieszyły się przedstawienia świetlne niemal od początku, zaniepokoiła władze szczebla centralnego i lokalnego. Infantylne początkowo scenki humorystyczne dość szybko przekształciły się w bowiem w różnego rodzaju bardziej lub mniej ambitne opowieści fabularne, których treść mogła się stać niebezpieczna dla ugruntowanego systemu politycznego, społecznego, a także powszechnie obowiązujących wzorców moralności. Prezydent regencji kwidzyńskiej Karl Schilling w piśmie skierowanym do podległych mu władz powiatowych z 29 III 1912 r. wskazywał, powołując się na opinie ministerialne, że rozwój teatrów kinematograficznych (nie tylko w wielkich, lecz także małych miastach) ujemnie wpływał na obyczajowość i mentalność oraz zagrażał zdrowiu psychicznemu i fizycznemu młodego pokolenia, które w sposób szczególny upodobało sobie tę nowinkę techniczną. „Nieodpowiednie i straszne” sceny wyświetlane na ekranach według kwidzyńskiego dygnitarza niekorzystnie oddziaływały na umysłowość, wrażliwość i wyobraźnię młodzieży. Treści płynące z przedstawień świetlnych miały także wpływać na zatracenie przez przedstawicieli młodego pokolenia umiejętności odróżniania dobra od zła. Ze względu na tego typu zagrożenia prezydent regencji nakazał znaczne ograniczenie obecności w kinach młodzieży uczęszczającej do szkół podległych jego jurysdykcji. W grudniu 1912 r. ukazało się również urzędowe rozporządzenie zabraniające wstępu do kinematografów dzieci poniżej szóstego roku życia ${ }^{13}$. $\mathrm{O}$ zakaz uczestnictwa nieletnich $\mathrm{w}$ przedstawieniach filmowych apelowali także hierarchowie katoliccy. Nawoływali do ograniczeń w udziale w seansach kinowych dorosłych wiernych i postulowali współuczestnictwo duchowieństwa parafialnego w nadzorze nad treścią rozpowszechnianych filmów. Władza biskupia w Pelplinie zobowiązywała księży diecezjalnych do ukazywania w kazaniach zagrożeń płynących z ekranów kin i zgubnego wpływu sztuki filmowej na kwestie moralności ${ }^{14}$.

Obawy przed prezentacją nieodpowiednich treści szybko doprowadziły do wprowadzenia cenzury filmów ukazujących się na ekranach kinowych. Na szczeb-

${ }^{12}$ Franz Pierberg, Thorn wie es um 1910 war, [in:] Thorn - Stadt und Land. Geschichten - Namens - Erinnerungen. 1231-1981, hrsg. v. Horst Ernst KRÜGER, Lüneburg 1981, s. 22-23; K. KluczwajD, op.cit., s. 254.

${ }^{13}$ APT, AMChn., sygn. 1540, prezydent regencji w Kwidzynie do landrata chełmińskiego, 29 III 1912 r.; prezydent regencji w Kwidzynie do landratów kwidzyńskiego okręgu regencyjnego, 8 XII 1912 r.; ibid., Akta miasta Golubia (dalej cyt. AMGol.), sygn. 390, landrat w Wąbrzeźnie do zarządu policji w Golubiu, 10 IV 1912 r.

${ }^{14}$ Beschlüsse der Fuldaer Bischofskonferenz vom 20 August 1913, Amtliches Kirchenblatt für die Diözese Culm, nr 10 z 27 X 1913 r.; Biskupi niemieccy wydali list pasterski, Gaz. Tor., nr 6 z 9 I $1914 \mathrm{r}$. 
lu lokalnym dokonywali jej urzędnicy miejskich zarządów policyjnych. Działania takie wpisywały się w panujący w II Rzeszy system kontroli, pozwalający organom policyjnym na uniemożliwienie publikacji dzieła lub wystawienia sztuki teatralnej ze względu na treść zagrażającą bezpieczeństwu publicznemu lub obyczajowości ${ }^{15}$. Zgodnie z obowiązującymi regulacjami władze regencyjne wydały w 1911 r. odpowiednią ordynację dotyczącą funkcjonowania kinematografów na terenie obwodu kwidzyńskiego. W myśl jej przepisów upowszechniane mogły być tylko obrazy, które przeszły kontrolę zarządu policyjnego w miejscowości, w której odbywało się przedstawienie, $\mathrm{z}$ wyjątkiem tych filmów, które miały już odpowiednie zezwolenie wydane przez Królewskie Prezydium Policji w Berlinie. Obrazy mogły być wyświetlane jedynie pod tymi tytułami, które zostały zgłoszone organom policji ${ }^{16}$. Urzędy policyjne w Prusach Zachodnich, analogicznie do innych obszarów Rzeszy, w celu ułatwienia sobie tej kontroli mogły abonować wydawane w Gubinie fachowe czasopismo pod nazwą „Verbotene Kinematographen-Bilder. Alfabetisches Verzeichnis verbotener Films zum Gebrauch für die Polizei-Behörden und Kinomatographen-Inhaber", będące $\mathrm{w}$ istocie spisem zakwestionowanych przez berlińskie władze policyjne filmów ${ }^{17}$. Ze względu na treść prezentowanych obrazów $\mathrm{w}$ tych pierwszych latach rozwoju kinematografii wprowadzono podział na seanse dostępne dla dzieci (odbywały się w godzinach popołudniowych) oraz projekcje przeznaczone dla osób dorosłych, odbywające się z reguły po godzinie 18 .

Restrykcje narzucane przez władze nie ograniczały rozwoju przedsiębiorstw kinematograficznych i nie były w stanie zahamować wzrastającej popularności seansów filmowych. Nieustannie podnosił się poziom artyzmu prezentowanych obrazów. Obok humoresek i scenek rodzajowych (filmy wyświetlane w zachodniopruskich miastach miały m.in. następujące tytuły, które niejako świadczą o ich treści: Der dicke Cowboy, Ein kleiner Irritum, Maschinenschreiberin wird gesucht) na ekranach pojawiały się także dramaty (wiosną 1914 r. na Pomorzu wyświetlano m.in. obraz In hoc signo vinces) ${ }^{18}$. Nawet w prowincjonalnych miastach, takich jak np. Chojnice, wyświetlane były ówczesne superprodukcje: Quo vadis czy Ostatnie dni Pompejów ${ }^{19}$. W przededniu wybuchu wojny światowej programy przedstawień filmowych wykazywały o wiele wyższy stopień ambicji niż te z początkowego okresu funkcjonowania kin. Oto przykładowy spis obrazów wyświetlanych na przełomie czerwca i lipca 1914 r. w jednym z toruńskich iluzjonów, opublikowany na łamach „Gazety Toruńskiej”:

\footnotetext{
${ }^{15}$ Hans J. Schütz, Cenzura w Rzeszy Wilhelmińskiej, [in:] Cenzura w Niemczech $w$ XX wieku. Studia, analizy, dokumenty, wybór i oprac. Czesław Karolak, Poznań 2000, s. 38-39.

${ }^{16}$ Por. APT, AMChn., sygn. 1540, „Polizei Verordnung betreffend den Ausüben der Zensur gegenüber Kinematographischen Schaustellungnen”, 2 II 1911 r.; ibid., AMGol., sygn. 390, Zarząd Policji w Golubiu do landrata w Wąbrzeźnie, 20 V 1911 r.

${ }^{17}$ Por. APB, AMN, sygn. 664; APT, Akta miasta Chełmży (dalej cyt. AMChż.), sygn. 1333; APT, AMGol., sygn. 390, landrat w Wąbrzeźnie do zarządu policji w Golubiu, 25 XI 1911 r.

${ }^{18}$ K. KLUCZWAJD, op.cit., s. 86.

${ }^{19}$ H. RzĄsKa, op.cit., s. 119.
} 
„1. Marya Stuart - dramat przez Fryderyka Schillera w trzech aktach;

2. Miłość Ojca - dramat w dwóch aktach;

3. Co kobieta sobie życzy - humor;

4. Ostatnia podróż do Santa Fe - dramat;

5. Juliusz i jego towarzysze - humor;

6. Żebym ja był Napoleonem - humor;

7. Tydzień Gaumonta, najnowsze zdarzenia z tygodnia"20.

Kinematografy stały się także narzędziami edukacji społecznej. Jeszcze przed $1914 \mathrm{r}$. w programach przedstawień świetlnych prezentowanych w kinach prowincjonalnych czy objazdowych obok filmów fabularnych często znajdowały się także te spełniające funkcję oświatową. Mieszańcy Chełmży (podobnie jak widzowie z Nowego nad Wisłą) mogli zatem w 1912 r. oglądać film z egzotycznych wysp Melanezji (wchodzących wówczas w skład imperium kolonialnego Rzeszy Niemieckiej) czy podziwiać widoki Alp ${ }^{21}$. Kino - także to prowincjonalne - nie było zatem jedynie formą taniej rozrywki. Niemal od początku głęboko zakorzeniło się w kulturze tamtych lat i stało się medium przekazującym i ukazującym $\mathrm{w}$ nowoczesnej formie wszelkie zagadnienia i problemy swej epoki ${ }^{22}$. W tym samym bowiem czasie, gdy widzowie toruńskich iluzjonów mogli się zapoznawać $\mathrm{z}$ historią królowej Szkotów Marii Stuart lub oglądać migawki z najważniejszych, aktualnych, wydarzeń politycznych, inne przedsiębiorstwa branży rozrywkowej oferowały osobliwości w rodzaju „zrośniętych sióstr z ich dzieckiem”23. Prezentowane w ówczesnych salach kinowych filmy znacząco więc odbiegały na korzyść od innych popularnych form masowej rozrywki. Kino stawało się sztuką i ważnym środkiem transmisji idei.

Ekrany prowincjonalnych iluzjonów pozwalały także widzom na przypatrzenie się panującemu i jego rodzinie. Osoba Wilhelma II oraz scenki z uroczystości państwowych z udziałem członków dynastii Hohenzollernów były często tematem wyświetlanych filmów, szczególnie zaś dodatków informacyjnych przygotowywanych przez producentów filmowych. Na ziemiach pomorskich, zróżnicowanych pod względem etnicznym i kulturowym, tego rodzaju pokazy stanowiły najpewniej element rozgrywającej się wówczas rywalizacji polsko-niemieckiej. Jednak narodowość zarówno widzów, jak i właścicieli kin w tych początkowym okresie działania kinematografów nie wydawała się odgrywać znaczącej roli. Programy kin poda-

${ }^{20}$ Teatr Kinematograficzny Metropol ul. Fryderykowska 7, Gaz. Tor., nr 147 z 2 VII 1914 r.

${ }^{21}$ APT, APChż., sygn. 1333, Anna Schweitzer z Chełmży do zarządu policji w Chełmży, 4 IV 1913 r.; 18 VII 1914 r.; APB, AMN, sygn. 664, Walter Meyer z Nowego do zarządu policji w Nowem, 12 XII $1912 \mathrm{r}$.

${ }^{22}$ Małgorzata Hendrykowska, Marek Hendrykowski, Film $w$ Poznaniu 1896-1945, Poznań 1990, s. 33.

${ }^{23}$ Wiosną 1914 r. w Toruniu można było oglądać gabinet osobliwości, którego największą atrakcją były „syjamskie” siostry Róża i Józefa Blażek, o czym informowały zarówno polskie, jak i niemieckie gazety. Zob. Sensacja dnia w Toruniu. Sensacyjna atrakcya, Gaz. Tor., nr 83 z 12 IV 1914 r.; Die zusammengewachsenen Blazek's Rosa und Josepha mit ihrem Sohne Franzl, Thorner Zeitung, nr 86 z 12 IV 1914 r. 
wane były zarówno przez gazety polskie, jak i niemieckie. Świadczy to pośrednio o tym, że mimo używania podczas przedstawień języka niemieckiego, w którym edytowano napisy, widowiska te były popularne także wśród ludności poczuwającej się (choćby przez lekturę codziennej prasy) do narodowości polskiej. Wynikało to $\mathrm{z}$ ogólnej fascynacji nowoczesnym wynalazkiem. Iluzjony powstawały zarówno w ośrodkach zdominowanych przez Niemców (m.in. Grudziądz, Gdańsk), jak i w miastach z dużym odsetkiem Polaków (Chełmno, Chełmża). Przedsiębiorcami byli zarówno Niemcy, jak i Polacy. Dla przykładu pierwszy stały kinematograf w Toruniu założyła Joanna Łyskowska, a w Chełmnie swych sił w tej nowej formie biznesu próbował Tomasz Kaniewski ${ }^{24}$. W przededniu wojny światowej skalę uczestnictwa $\mathrm{w}$ przedstawieniach kinematograficznych wśród mieszkańców Pomorza Nadwiślańskiego można określić jako powszechną. Dowodem na to niech będzie fakt ubiegania się przez mieszkankę Chełmży Annę Schweitzer (późniejszą właścicielkę tamtejszego kina stałego o nazwie „Lichtspielpalast”) o zezwolenie na urządzanie przedstawień kinematograficznych w każdy dzień tygodnia (od poniedziałku do soboty od godziny 17.00 do 23.00, a w niedzielę od 15.00 do 23.00) oraz o możliwość organizacji seansów przeznaczonych wyłącznie dla dzieci w okresie wakacyjnym ${ }^{25}$. Około 1914 r. stałe kina znajdowały się niemal w każdym mieście powiatowym prowincji zachodniopruskiej. Przeciętnie obiekty takie przeznaczone były na około 200 widzów. W większych ośrodkach funkcjonowało kilka iluzjonów (np. w Gdańsku 7, w Toruniu 4, w Grudziądzu 4, w Elblągu 4, w Chełmnie 2) ${ }^{26}$. Prezentacja ruchomych obrazów jako forma dodatkowego zarobkowania była szczególnie popularna wśród właścicieli restauracji i lokali gastronomicznych, którzy w tego rodzaju działalności dostrzegali możliwość przyciągnięcia klienteli. Dotyczyło to głównie mniejszych miejscowości, m.in. Chełmży czy Nowego nad Wisłą. W Kwidzynie pierwszy stały kinematograf pod nazwą „Lichtspielhaus” otworzył Franz Barra, właściciel jednego z tamtejszych hoteli z „elegancką" restauracją ${ }^{27}$.

Pierwsza wojna światowa przyniosła ze sobą przemiany społeczne i obyczajowe, które objęły także mieszkańców Pomorza Nadwiślańskiego ${ }^{28}$. Wieloaspektowe

${ }^{24}$ APT, AMChn., sygn. 1540, Miejski Urząd Budowlany w Chełmnie do Królewskiej Landratury w Chełmnie, 2 XII 1910 r.; K. KLUCZWAJD, op.cit., s. 88.

${ }^{25}$ APT, AMChż., sygn. 1333, Anna Schweitzer do zarządu policji w Chełmży, 3 IX 1912 r. Por. Piotr BIRECKI, Dynamika życia kulturalnego małego miasteczka na przykładzie Chełmży, [in:] Życie codzienne w regionie kujawsko-pomorskim, red. Waldemar Rozynkowski, Małgorzata STRzeleckA, Toruń 2011, s. 121-122.

${ }^{26}$ Por. M. Andrzejewski, $Z$ dziejów, s. 16; K. Kluczwajd, op.cit., s. 90-91; Marta Siebert, Das gab es alles in Graudenz. Ein Bummel durch Graudenzer Gastätten, Geschäfte und anders, Der Westpreuße, nr 15 z 3 VIII 1974 r., s. 14; Hans Huth, Die Kulmer!, [in:] Kulm an der Weichsel. Stadt und Land im Wechsel der Geschichte 1332-1982, hrsg. v. Horand Henatsch im Zusammenarbeit mit Günter MEINHARDT, Bremervörde 1982, s. 233.

${ }^{27}$ Adressbuch der Stadt Marienwerder mit den Vororten Mareese, Marienau und Schäferei für das Jahr 1912, Teil 2: Personen- und Firmen-Register in alphabetischer Reihenfolge, Marienwerder 1912, s. 3.

${ }^{28}$ Tomasz Krzemiński, Wojenna codzienność na Pomorzu Nadwiślańskim w latach 1914-1918, Czasy Nowożytne, t. 27: 2014, s. 185-211. 
oddziaływanie konfliktu wpłynęło również na funkcjonowanie kin w regionie i odbiór tego wciąż nowego medium. Bardzo szybko stało się ono doskonałym narzędziem propagandy państwa prowadzącego wojnę, która z wolna nabierała charakteru totalnej. Władze pruskie starały się poddać funkcjonowanie iluzjonów rygorom prowadzonej polityki informacyjnej i wpływały na repertuar kin (na ekranach pojawiły się wówczas obrazy gloryfikujące armię, filmy propagujące przywiązanie do dynastii czy hołubiące bohaterów wojennych). Oddziaływało to na nastroje ludności, a także mobilizowało do różnorodnych akcji na rzecz wysiłku zbrojnego. Doskonałym przykładem na tego rodzaju zastosowanie filmu była m.in. inicjatywa Towarzystwa Geograficznego z 1916 r., popierana przez nadprezydenta prowincji zachodniopruskiej Ernsta von Jagowa, która polegała na wyświetlaniu przedstawień kinematograficznych, z których dochód przeznaczono na pomoc inwalidom wojennym ${ }^{29}$. Podobne w formie wykorzystanie „ruchomych obrazów” zastosowano podczas tzw. Kwesty Ludendorfa (Ludendorf-Spende). Zbiórkę przeprowadzaną w początkach czerwca $1918 \mathrm{r}$. na rzecz inwalidów poszkodowanych na wojnie i ich rodzin poprzedzały specjalne projekcje filmu propagandowego m.in. w toruńskim iluzjonie "Odeon" ${ }^{30}$. Kina z miejsc o charakterze niemal wyłącznie rozrywkowym w czasie wojny światowej zaczęły się przekształcać w ośrodki transmisji odpowiednich informacji i kreowania nastrojów społecznych. Z końcem 1914 r., zgodnie z ministerialnymi wskazówkami, nakazano wyświetlać tylko obrazy dostosowane swą treścią do „powagi czasów”. Zakazano także prezentacji filmów wyprodukowanych $\mathrm{w}$ krajach nieprzyjacielskich ${ }^{31}$. Wojna przyniosła również zmiany $\mathrm{w}$ charakterze udziału ludności w seansach. Rozluźnienie kontroli rodzicielskiej wobec młodzieży (większość ojców służyła w wojsku, a matki zajęte były zapewnieniem utrzymania rodziny) doprowadziło do uzyskania przez osoby młode znaczniejszego zakresu swobody niż do tej pory. Jednym z najpopularniejszych sposobów spędzania wolnego czasu stał się wówczas udział w przedstawieniach kinematograficznych. Uczestnictwo młodzieży w przedstawieniach świetlnych musiało być na tyle uciążliwe, że władze wojskowe (generał komenderujący okręgiem korpusu, a także poszczególni komendanci i gubernatorzy twierdz), którym podlegała wówczas administracja, wielokrotnie powtarzały zakazy i ograniczenia w korzystaniu $\mathrm{z}$ kin przez osoby nieletnie ${ }^{32}$. Ucieczka $\mathrm{w}$ świat filmowej iluzji charakteryzowała również liczną grupę udręczonych wojenną codziennością kobiet, którym jednak wypominano uczestnictwo w seansach. Pojawiały się nawet groźby odebrania amatorkom

${ }^{29}$ APT, AMChż., sygn. 1333, nadprezydent prowincji Prusy Zachodnie do landratów prowincji, 19 I $1916 \mathrm{r}$

${ }^{30}$ Ibid., Akta Osób i Rodzin - zbiór szczątków zespołów z lat 1701-1973, sygn. 14, nadburmistrz do naddyrektora liceum w Toruniu, $28 \mathrm{~V} 1918 \mathrm{r}$.

${ }^{31}$ Ibid., AMChn., sygn. 1540, prezydent regencji w Kwidzynie do landratów obwodu regencyjnego, 31 XII $1914 \mathrm{r}$.

${ }^{32}$ Por. ibid., komenderujący generał 17 korpusu, gubernatorzy twierdz w Toruniu i Grudziądzu, komendanci twierdz w Gdańsku, Chełmnie i Malborku do ludności okręgu 17 korpusu armijnego, 8 XII $1915 \mathrm{r}$. 
ruchomych obrazów zapomogi wojennej przysługującej im z racji frontowej służby męża. W obronie prawa kobiet do rozrywki stanęła m.in. redakcja „Gazety Gdańskiej”, wskazując, że: „kobieta ta prawdziwa męczennica i bohaterka pragnie wieczór jakiejś taniej a godziwej rozrywki, i że większość ich szuka jej w kinie, które stało się dzisiaj jedną z popularnych ludowych przyjemności. Wszystko co żyje potrzebuje pewnej dozy wesołości, zupełnie jak roślina słońca. Nie odbierajmy biednym kobietom tego strzępa wesołości biurokratycznym gwałtem!" ${ }^{33}$. Trudy czasu wojny powodowały, że ludność Pomorza, stanowiącego głębokie zaplecze toczących się krwawych zmagań, odnajdywała zapomnienie w przedsięwzięciach rozrywkowokulturalnych. Dlatego też, jak wspominał jeden z pamiętnikarzy, opisując ówczesny Gdańsk: „restauracje i kawiarnie [były] pełne, jak w czasie pokoju, tak samo kinematografy, teatr miejski daje przedstawienia [...]"34. Podobnie było w innych ośrodkach miejskich regionu ${ }^{35}$. Działania ograniczające uczestnictwo w seansach, a także pogłębiające się trudności materialne ${ }^{36}$ nie zahamowały rozwoju przedsiębiorstw kinematograficznych. Mimo ograniczeń w dostawach energii i powszechnej pauperyzacji iluzjony nie zamykały podwojów dla chętnych wrażeń i informacji widzów. Obok funkcjonujących dawniej powstawały wówczas także nowe przybytki X Muzy. W 1915 r. w Chełmży rozpoczął działalność drugi w tym miasteczku stały kinematograf, urządzony w sali tamtejszej restauracji „Concordia”37. W $1917 \mathrm{r}$. Hugo Gandrass założył w Tczewie kino pod nazwą "Lichtspielhaus” z widownią zaopatrzoną w 400 miejsc. Przedstawienia filmowe musiały więc przynosić stały, w miarę bezpieczny dochód $\mathrm{w}$ tych niepewnych czasach wszelkich niedoborów. Rekompensowały zatem straty ponoszone przez inwestujących w nową formę rozrywki właścicieli lokali gastronomicznych czy hotelarskich.

Klęska wilhelmińskich Niemiec i będące jej konsekwencją postanowienia kongresu wersalskiego z 1919 r. przyczyniły się do podziału terenów dotychczasowej prowincji Prusy Zachodnie między trzy organizmy polityczno-państwowe: Polskę, Rzeszę Niemiecką oraz Wolne Miasto Gdańsk. Nowe uwarunkowania polityczne wpłynęły także na funkcjonowanie przedsiębiorstw kinowych. W wyniku exo-

\footnotetext{
${ }^{33}$ Czy kobiety pobierajace zasitki wojskowe powinny bywać w kawiarniach i kinematografach?, Gazeta Gdańska nr 115, 23 IX 1916 r.

${ }^{34}$ Gdańsk w latach I wojny światowej (1914-1918) w świetle pamiętnika ks. Bolesława Makowskiego, [in:] Mieczysław Wojcı́chowsкi, Miasta Pomorza Nadwiślańskiego i Kujaw w okresie I wojny światowej oraz w międzywojennym dwudziestoleciu (1914-1939), Toruń 2000, s. 506.

${ }^{35}$ Tomasz Krzemiński, Codzienność mieszkańców Torunia w latach pierwszej wojny światowej (1914-1918), Rocznik Toruński, t. 41: 2014, s. 60; idem, Doświadczenia codzienności mieszkańców Grudziądza w czasie pierwszej wojny światowej (1914-1918), Rocznik Grudziądzki, t. 22: 2014, s. 131.

${ }^{36} \mathrm{Na}$ mocy ogólnoniemieckich przepisów w 1916 r. ograniczono czas funkcjonowania kinematografów, które winny być bezwzględnie zamykane o godzinie 22.00 , zob. W celu zaoszczędzenia światła $i$ wegli, Gaz. Tor., nr 288 z 16 XII 1916 r.

${ }^{37}$ Zob. APB, Urząd Wojewódzki Pomorski w Toruniu (dalej cyt. UWP), sygn. 5048, magistrat miasta Tczewa do wojewody pomorskiego w Toruniu, 20 XI 1929 r. Por. M. ANDrZejewski, Z dziejów, s. 17; P. BireCKI, op.cit., s. 122.
} 
dusu ludności niemieckiej z terenów województwa pomorskiego, który nastąpił w początkach lat dwudziestych, wiele kinematografów zmieniało właścicieli, przechodząc w ręce Polaków. W wielu przypadkach byli to ludzie pochodzący spoza Pomorza, traktujący zakup tego typu przedsiębiorstwa jako inwestycję rokującą wysokie i pewne zyski. Przykładowo jedno z toruńskich kin, znajdujące się przy ul. Mickiewicza, w ciągu pół roku zmieniło kilku właścicieli. Początkowo lokal zdatny do urządzenia iluzjonu wydzierżawił pochodzący z niedalekiego Aleksandrowa Kujawskiego (położonego jednak za dawnym kordonem) Adam Piechocki, który ze wspólnikiem Bolesławem Górskim wszedł w prawo własności obiektu jesienią $1921 \mathrm{r}$. Wówczas też rozpoczęły się przedstawienia kinematograficzne. Jednak już w marcu następnego roku kino nabył Aleksander Bychowski, prawnik pochodzący z Wilna i były oficer wojsk polskich ${ }^{38}$. W okresie przejściowym zdarzały się także przypadki dzierżawy przedsiębiorstw kinowych od zamieszkujących już w Niemczech właścicieli przez najemców Polaków, co również było powodem do animozji międzydzielnicowych - charakterystycznego zjawiska tamtych czasów ${ }^{39}$. Powojenne zawirowania ekonomiczne i związany z tym znaczny stopień zubożenia społeczeństwa zarówno w części Pomorza włączonej do niepodległej Rzeczypospolitej, jak i w Gdańsku czy fragmentach pozostałych w granicach Niemiec nie stały się przeszkodą w rozwoju przedsięwzięć kinowych. Pod tym względem lata dwudzieste także na Pomorzu były, podobnie jak w Stanach Zjednoczonych i państwach Europy Zachodniej, złotą erą kina ${ }^{40}$. Powszechność i popularność seansów filmowych, powiązana ze wzrastającą produkcją filmową, stały się zjawiskami znamionującymi przekształcenie kinematografii w element zachodniej kultury masowej. Masowej przede wszystkim ze względu na liczne uczestnictwo widzów w przedstawieniach kinematograficznych, które odbywały się z reguły codziennie i cieszyły się dużą frekwencją uczestników ${ }^{41}$. Wyrazem masowości korzystania z nowego medium była także różnorodność zarówno tematyczna, jak i geograficzna ze względu na kraj pochodzenia filmów wyświetlanych na ekranach prowincjonalnych iluzjonów. I choć na początku okresu przeważały jeszcze w kinach polskiego

${ }^{38}$ APT, Akta miasta Torunia, sygn. D 4638, Aleksander Bychowski do magistratu miasta Torunia, 17 III $1922 \mathrm{r}$.

${ }^{39}$ Toruńskie kino „Odeon” znajdujące się w 1922 r. wciąż w rękach właściciela narodowości niemieckiej zamieszkującego w Berlinie było dzierżawione polskim przedsiębiorcom. Kontrowersje wywołała zmiana dzierżawcy, którą została „pochodząca spoza dzielnicy p. Kellerowa, ustosunkowana u władz”, por. W sprawie kina „Odeon”, Głos Robotnika. Organ Narodowej Partji Robotniczej na Pomorze i okręg nadnotecki, nr 154 z 8 VII 1922 r. O animozjach międzydzielnicowych zob. w: Janusz Kutta, „My” $i$ „oni” na Pomorzu w latach 1920-1939. Przyczynek do dziejów integracji społeczeństwa polskiego, Zapiski Historyczne, t. 56: 1991, z. 2-3, s. 59-85.

${ }^{40}$ Dzieje kinematografii w okresie międzywojennym na obszarze Wolnego Miasta Gdańska wyczerpująco przedstawił w swej monografii: M. ANDRZEJEwski, $Z$ dziejów, s. 19-58.

${ }^{41}$ Elżbieta BRZESKA, Uczestnictwo $w$ kulturze mieszkańców małych miast pomorskich na przykładzie Chojnic w 20-leciu międzywojennym, [in:] Z dziejów kultury Pomorza XVIII-XX wieku, t. 2: Materiały z seminarium na Uniwersytecie Gdańskim, 14 marca 2003 roku, red. Józef Borzyszkowski, Cezary Obracht-Prondzyński, Gdańsk 2004, s. 230. 
Pomorza obrazy produkcji niemieckiej ( $w$ tym bardzo wiele starych pochodzących jeszcze sprzed $1914 \mathrm{r}$.), to z czasem ta swoista hegemonia została przełamana i na ekranach zagościły przede wszystkim produkcje pochodzące zza oceanu, choć wytwórczość europejska i krajowa były także silnie reprezentowane ${ }^{42}$.

W okresie powojennym wzrosła znacznie kwestia upolitycznienia spraw związanych z filmem i kinematografią, co na Pomorzu silnie wiązało się z nasilającym się z każdym rokiem konfliktem polsko-niemieckim. Dla władz państwowych istotna stała się kwestia szczegółowej kontroli nad kinami, które pozostały w rękach właścicieli niemieckich, a także nad treścią prezentowanych w iluzjonach filmów. Wojewoda Jan Brejski w okólniku skierowanym do podległych mu starostów nakazywał stosowanie ścisłej cenzury, gdyż jak zauważył: „Nie można pozwolić na germanizację i demoralizację ludności naszej za pośrednictwem kinematografów"43. Władze polskie nie godziły się na wyświetlanie filmów zaopatrzonych jedynie w napisy niemieckie. Brak polskiej wersji językowej nie stanowił jednak przeszkody dla oglądających je widzów. Policja kontrolująca przybytki $\mathrm{X}$ Muzy sprzeciwiała się jednak emisji tego typu obrazów, co z kolei powodowało niezadowolenie publiczności. W Kościerzynie w obronie niemieckojęzycznego filmu opowiadającego o walkach na froncie palestyńskim w okresie wojny światowej stanął oglądający go oficer żandarmerii wojskowej, wchodząc w ostrą polemikę $\mathrm{z}$ nakazującym przerwanie seansu posterunkowym policji ${ }^{44}$. Względy ekonomiczne sprawiały jednak, że w pierwszych latach po odzyskaniu niepodległości filmy niemieckie dominowały w repertuarze prowincjonalnych kin. Niektórzy przedstawiciele władz widzieli w tym „upośledzenie języka polskiego przez hakatystyczno-żydowskie kina"45. Projekcja filmów stała się zatem swego rodzaju narzędziem prowadzonej rywalizacji nacjonalistycznej. Często działo się to w sposób niezamierzony za sprawą właścicieli kin lub dystrybutorów obrazów. Ostry protest jednego z toruńskich widzów wzbudził film produkcji szwedzkiej pt. Tajemnice zamku sandomierskiego opowiadający o epizodzie z okresu drugiej wojny północnej z lat 1655-1660. W sposób niekorzystny miał on przedstawić Polaków. Zarządzone przez wojewodę dochodzenie w tej sprawie ustaliło jednak, że film został ocenzurowany i dopuszczony przez Ministerstwo Spraw Wewnętrznych, które nie dopatrzyło się w nim żadnych tego typu treści. W uzasadnieniu swych wywodów dyrektor departamentu MSW wskazał jednak na potrzebę umiejętnego dopierania repertuaru dla kin pomorskich, podkreślając, że „Zwłasz-

\footnotetext{
${ }^{42}$ Dla przykładu w lipcu, sierpniu i we wrześniu 1936 r. na ekranie objazdowego kina w Nowem z 15 wyświetlanych wówczas tytułów tylko trzy były produkcji polskiej, por. APB, UWP, sygn. 5074, starosta powiatowy w Świeciu do wojewody pomorskiego w Toruniu, wrzesień $1936 \mathrm{r}$.

${ }^{43}$ Ibid., sygn. 5020, k. 9, wojewoda pomorski do starostów powiatowych, 26 X 1920 r.

${ }^{44}$ Ibid., sygn. 5034, posterunek Policji Państwowej w Kościerzynie do Starostwa Powiatowego w Kościerzynie, 13 VI $1921 \mathrm{r}$.

${ }^{45}$ Ibid., sygn. 5020, Dowództwo Okręgu Generalnego Pomorze do wojewody pomorskiego, 23 XII $1920 \mathrm{r}$.
} 
cza Pomorze innych wymaga obrazów o Polakach"46. Również pomorscy Niemcy odczuwali oddziaływanie nieprzychylnych ich narodowości treści niektórych wytworów ówczesnej sztuki filmowej prezentowanych na ekranach kin regionu. Konsul niemiecki interweniował m.in. w sprawie filmu Bartek Zwycięzca, który „W swojej tendencji był nieprzyjazny Niemcom” i nie odpowiadał „przyjaznym stosunkom, które po zawarciu pokoju stosownie do ponownych oświadczeń obustronnych polityków istnieją pomiędzy obu państwami”. Podobną reakcję wywołała produkcja francuska pt. Czterej jeźdźcy apokalipsy w jednoznaczny sposób ukazująca Niemców jako sprawców zbrodni wojennych w latach $1914-1918^{47}$. Ze zmieniającą się ogólną sytuacją polityczną i wzrostem w Rzeszy wpływów hitleryzmu potęgowała się niechęć Polaków do coraz bardziej agresywnego niemieckiego sąsiada. Odbijało się to na odbiorze i postrzeganiu niemieckich filmów. Po serii wyborów parlamentarnych z początku 1933 r. w Niemczech, w wyniku których władzę uzyskał Adolf Hitler, widzowie gdyńskiego kina „Morskie Oko” z dużym niezadowoleniem przyjęli emisję gloryfikującego bohaterstwo żołnierzy niemieckich filmu Pod fałszywa flagą. Kino obrzucono kamieniami, a komisarz rządu, w obawie przed zamieszkami, wydał zakaz wyświetlania obrazu ${ }^{48}$. W tym samym czasie Związek Obrony Kresów Zachodnich wezwał do bojkotu filmów niemieckich, co poparły także organizacje branżowe przedsiębiorców kinowych $\mathrm{z}$ terenu województwa pomorskiego ${ }^{49}$.

Wzrastająca popularność sztuki filmowej połączona z brakiem jednolitego, urzędowego schematu radzenia sobie $\mathrm{z}$ wynikającymi przy tej okazji potencjalnymi problemami (w odniesieniu do zasad prowadzenia kin wciąż obowiązywały pruskie przepisy, m.in. ordynacja przemysłowa) były przyczyną bardzo skrupulatnego kontrolowania przez organy państwowe przepływu filmów oraz funkcjonowania kin. Wiązało się to z dużą wysokością wpływów fiskalnych na rzecz skarbu państwa i budżetów samorządowych uiszczanych przez właścicieli kin, a także ceł pobieranych od sprowadzanych z zagranicy obrazów. Jak donosiło bowiem wojewodzie pomorskiemu w styczniu 1924 r. Ministerstwo Spraw Wewnętrznych, dochody z opłat celnych pobieranych przy wwożeniu filmów w granice Rzeczypospolitej „stają na trzeciem lub czasem na czwartem miejscu” wszystkich wpływów celnych ${ }^{50}$. Na równie wysokie przychody podatkowe mogły liczyć także kasy samorządowe pobierające bezpośredni podatek od przedsiębiorców kinowych. W Toruniu na początku lat dwudziestych sumy te wynosiły według opinii użalają-

${ }^{46}$ Ibid., sygn. 5034, k. 339, Ministerstwo Spraw Wewnętrznych w Warszawie do wojewody pomorskiego w Toruniu, 15 I 1924 r.

${ }^{47}$ Ibid., k. 337, 591-593, konsul niemiecki w Toruniu do Urzędu Wojewódzkiego Pomorskiego w Toruniu, 1 XII 1923 r.; 20 XI 1924 r.

${ }^{48}$ Ibid., sygn. 5050, Komisariat Rządu w Gdyni do Urzędu Wojewódzkiego Pomorskiego w Toruniu, 29 III 1933 r.; P. ŚLIWIŃSKA, op.cit., s. 102.

${ }^{49}$ K. KLUCZWAJD, op.cit., s. 31.

${ }^{50}$ APB, UWP, sygn. 5050, k. 537, Ministerstwo Spraw Wewnętrznych do wojewody pomorskiego w Toruniu, 3 I 1924 r. 
cych się na zwiększające się daniny właścicieli iluzjonów ponad 7 tysięcy złotych miesięcznie ${ }^{51}$. W Gdyni liczba biletów sprzedawanych na seanse filmowe rosła nieustannie i w przeciągu zaledwie pięciu lat z $340441 \mathrm{w} 1932$ r. osiągnęła wymiar 815 357 w 1937 r., co przekładało się na równowartość ponad 700 tysięcy złotych przychodu rocznego ${ }^{52}$. W podtoruńskim Podgórzu w jednorazowym seansie uczestniczyły 274 osoby, a dochód z takiego pokazu wyniósł 162,10 zł ł3 $^{53}$ Dane te pośrednio wskazują, jaką popularnością cieszyły się wówczas seanse filmowe.

Wysoka rentowność kinematografów powodowała zjawiska przestępcze związane z nielegalnym przemytem filmów do Polski, co w znacznej mierze ułatwiało istnienie Wolnego Miasta Gdańska, przez którego terytorium wwożono filmy zagraniczne bez uiszczania odpowiednich opłat. W obiegu między poszczególnymi kinami krążyło także wiele niezarejestrowanych filmów, co narażało na straty zarówno skarb państwa, jak i dochody producentów filmowych oraz różnego rodzaju pośredników (m.in. właścicieli wypożyczalni filmów). Nadzieje na zyski związane $\mathrm{z}$ produkcją filmową leżały u podstawy różnego rodzaju przedsięwzięć, jakie w okresie międzywojennym realizowano na Pomorzu. W Toruniu przez krótki czas funkcjonowała wytwórnia filmowa prowadzona przez Bernarda Marwińskiego, w której powstał obraz Panienka $z$ chmur $^{4}$. Zmagający się z problemami gospodarczymi ziemianie pomorscy udostępniali plenery swych majątków i wnętrza dworów dla ekip realizujących filmy ${ }^{5}$. Jan Sikorski z Wielkich Chełmów, przedstawiciel jednej z najbardziej zasłużonych familii ziemiańskich regionu, próbował swych sił (bez sukcesu) w branży filmowej, widząc w tym możliwość pozarolniczej aktywności gospodarczej w trudnych dla działalności agrarnej czasach $^{56}$. Film umożliwiał także osiągnięcie sławy i kariery aktorskiej. Przykładem błyskotliwego sukcesu była torunianka Helena Grossówna, urodzona w 1904 r., która w latach trzydziestych stała się jedną z najbardziej rozpoznawalnych gwiazd polskiego ekranu.

Po przewrocie majowym 1926 r. władze starały się wzmóc kontrolę działających $\mathrm{w}$ regonie przedsiębiorstw kinowych. Zamach stanu przeprowadzony przez marszałka Józefa Piłsudskiego został bowiem przyjęty na Pomorzu bardzo niechętnie, a w okresie późniejszym utrzymywały się niezwykle silne nastroje opozycyjne względem tworzonego przez sanację systemu politycznego ${ }^{57}$. W okresie poprzedzającym wybory parlamentarne w $1928 \mathrm{r}$. minister spraw wewnętrznych gen. Felicjan S. Składkowski nakazywał władzom wojewódzkim ścisłą kontro-

${ }^{51}$ K. KLuCzwajd, op.cit., s. 93.

${ }^{52}$ P. ŚLIWIŃSKA, op.cit., s. 85.

${ }^{53}$ APT, Akta miasta Podgórza, sygn. 2241, rozliczenia przedstawione kasie miejskiej w Podgórzu przez P. Krzyżewskiego z Brodnicy, 15 III 1930 r.

${ }^{54}$ Widowiska świetlne, Słowo Pomorskie nr 283 z 7 XII 1929 r.

55 Tomasz Łaszkiewicz, Ziemiaństwo na Pomorzu w okresie dwudziestolecia międzywojennego - w perspektywie codzienności, Inowrocław-Toruń 2013, s. 104.

${ }^{56}$ Jan Sikorski, Ziemianin bez kompleksów. Wspomnienia, oprac. Józef BorZYsZKowski, Gdańsk 1990, s. 55

${ }^{57}$ Por. Przemysław Olstowski, Obóz pomajowy w województwie pomorskim w latach 1926-1939, Warszawa 2008, s. 33 n. 
lę przedsiębiorstw kinematograficznych, aby: „czynniki niepożądane nie mogły wyzyskiwać dla propagandy swych haseł tak ważnych środków agitacji, jakiemi mogą stać się film i kino" ${ }^{58}$. Licząc się z siłą oddziaływania nowego medium, władze wywierały też presję na właścicieli kin w celu regularnego wyświetlania kronik Polskiej Agencji Telegraficznej, upatrując w tym ważny czynnik w kształtowaniu postaw propaństwowych. Wysokie koszty abonamentu powodowały jednak, że przedsiębiorcy robili to niechętnie i decydowali się na to dopiero pod wyraźnym naciskiem poszczególnych starostów ${ }^{59}$. Nakazywano także wyświetlanie filmów propagujących kult marszałka Piłsudskiego, często nie bacząc na rygorystycznie dotąd przestrzegane przepisy dotyczące rejestracji obrazów ${ }^{60}$.

Na przełomie lat dwudziestych i trzydziestych kino stało się już istotnym środkiem wpływającym na nastroje społeczne na terenie województwa pomorskiego i stanowiło dla władz polskich doskonałą broń w propagowaniu idei przywiązania do narodowości polskiej w odniesieniu do wciąż silnie oddziałującej na ludność regionu kultury niemieckiej i trudnych do wykorzenienia resentymentów do Niemiec i niemczyzny. Poświadcza to opinia starosty tczewskiego w sytuacji, gdy komisja wojewódzka zakwestionowała warunki techniczne kina „Igrzyska Świetlne” i wymogła na jego właścicielu Hugo Gandrassie (obywatelu niemieckim) czasowe zamknięcie przedsiębiorstwa. W tajnym piśmie do wojewody szef administracji powiatowej donosił: „Kino w Tczewie jest potrzebne i należy dążyć do jak najszybszego uruchomienia jego, tem bardziej że obecnie szereg osób jeździ do kin w Gdańsku. Stan ten jest pod wszelkiemi względami wysoko szkodliwym" ${ }^{\prime 1}$. Odgórnym rozporządzeniem wprowadzono także nakaz wyświetlania filmów produkcji polskiej, które miały stanowić 10 procent prezentowanych obrazów ${ }^{62}$.

Popularność sztuki filmowej, zarówno tej pochodzącej zza oceanu, jak i twórczości rodzimej, wzbudzała obawy nacjonalistycznie nastawionej prasy polskiej (przodowało w tym głównie popularne w regionie „Słowo Pomorskie”), która informowała i przestrzegała swych czytelników - i zarazem częstych widzów kinowych - przed popieraniem tych dzieł, które powstały na bazie kapitałów lub zaangażowania artystycznego osób pochodzenia żydowskiego ${ }^{63}$.

${ }^{58}$ APB, UWP, sygn. 5044, Minister Spraw Wewnętrznych do wojewody pomorskiego w Toruniu, 16 I 1928 r.; APT, AMGol., sygn. 390, wojewoda pomorski do starostów i prezydentów miast, 23 I $1928 \mathrm{r}$.

${ }^{59}$ Ibid., sygn. 5051, starosta grodzki w Grudziądzu do wojewody pomorskiego w Toruniu, czerwiec $1928 \mathrm{r}$.

${ }^{60}$ W Golubiu tamtejsze kino w 1928 r. „aż od odwołania” miało wyświetlać film Hołd Marszałkowi, mimo że nie miał on stosownej legitymacji filmowej (za co w innym przypadku właścicielowi kina groziły wysokie kary), zob. APT, AMGol., sygn. 390, starosta wąbrzeski do urzędów policyjnych w Golubiu, Kowalewie i Wąbrzeźnie, 7 III 1928 r.

${ }^{61}$ APB, UWP, sygn. 5048, starosta powiatowy w Tczewie do wojewody pomorskiego w Toruniu, 3 II $1930 \mathrm{r}$.

${ }^{62}$ APT, AMGol., sygn. 390, Minister Spraw Wewnętrznych do wojewody pomorskiego, 24 III $1930 \mathrm{r}$.

${ }^{63}$ K. KLuCZWAJD, op.cit., s. 43-44.

W w w. zapis kih istoryczne.pl 
Oprócz kontrowersji natury politycznej wyświetlane przez pomorskie kina filmy wzbudzały także spory dotyczące sfery moralnej. Ekspansja wytworów kinematografii amerykańskiej związana była z rozbudowanymi działaniami reklamowymi, do których nie byli jeszcze w pełni przygotowani mieszkańcy ówczesnego Pomorza. W grudniu 1925 r. wojewoda pomorski zmuszony był interweniować $\mathrm{w}$ sprawie odsłaniających zbyt wiele kobiecego ciała reklam umieszczanych w gablotach wystawianych przed kina. Plakaty zawierały bowiem „fotografje aktorek z obnażonemi piersiami”. Treści te oglądane przez dzieci i młodzież miały negatywnie wpływać na ich rozwój psychiczny ${ }^{64}$. Jeden z czytelników „Słowa Pomorskiego" postulował w 1922 r. zaostrzenie cenzury przedstawień filmowych, które według jego opinii wywierały „na społeczeństwo względnie na młodzież naszą wpływ wprost zabójczy"65.

Dla młodych ludzi wizyta w iluzjonie wiązała się wówczas z silnymi przeżyciami emocjonalnymi. Jak wspominał po latach uczeń wejherowskiego gimnazjum Bolesław Bok: „pod wpływem filmów, w większości przeznaczonych dla dorosłych widzów, wybujała moja i tak już chorobliwa wyobraźnia" ${ }^{66}$. Nic więc dziwnego, że wszelkiej maści obrońcy moralności starali się ograniczać zgubne skutki oddziaływania sztuki filmowej na nieprzygotowane do jej odbioru umysły. „Jest to ogólnym objawem po wojnie, że wyuzdane pisma, powieści, bezwstyd w piśmie i obrazach, w kinie, teatrze i w tańcu, w ogóle pornografja i rozpusta wszelkiego rodzaju rozpanasza się nie tylko po większych miastach, ale już i po małych miasteczkach i wioskach i jakby trąd straszne czyni spustoszenie nieraz w najlepszych rodzinach" prezentował ówczesną rzeczywistość orędownik diecezjalny, postulując współpracę duchowieństwa katolickiego $\mathrm{z}$ władzami nad kontrolą widowisk kinowych oraz wzmożoną pracę duszpasterską $\mathrm{z}$ rodzicami w celu odciągnięcia młodego pokolenia od negatywnych treści płynących $z$ ekranó $w^{67}$. Ścisłe zakazy nakładano na kwestię udziału w seansach dzieci i młodzież ${ }^{68}$. Mimo jednak tej prohibicji nastolatki w przemyślny sposób potrafiły się wemknąć do sali kinowej. Łucja Kitzner-Kędzierska tak wspomina okoliczności związane z nielegalną wizytą grupy uczennic Państwowego Gimnazjum Humanistycznego w wąbrzeskim iluzjonie: „Oczywiście nie było mowy o wyjściu do kina, co byłoby już skandalem. Pamiętam jak w 1927 roku, $\mathrm{w}$ trakcie przerwy maturalnej pomiędzy egzaminem pisemnym a ustnym wybraliśmy się potajemnie całą grupą do kina na «Flipa i Flapa». Wówczas cała «obstawa» stała przed kinem, aby ostrzec nas przed prawdopodobnym pojawieniem się «Rexa»

${ }^{64}$ APT, AMChm., sygn. 1540, wojewoda pomorski do starostów i prezydentów miast województwa pomorskiego, 5 XII $1925 \mathrm{r}$.

${ }^{65}$ Cyt. za: K. Kluczwajd, op.cit., s. 111.

${ }^{66}$ Bolesław BoK, Ścieżki, bezdroża i drogi, Gdańsk 1984, s. 137.

${ }^{67}$ Franciszek Czapliśski, Źródła dzisiejszej demoralizacji $i$ walk z nią, Miesięcznik Diecezji Chełmińskiej (dawniej Orędownik Kościelny), nr 5, 1930 r., s. 344.

${ }^{68}$ APB, UWP, sygn. 5026, k. 41, rozporządzenie policyjne dotyczące uczestnictwa nieletnich $\mathrm{w}$ publicznych przedstawieniach kinematograficznych. 
[nauczyciela kontrolującego kino - T.K.]"69. Negatywnie do kinowej rozrywki podchodziło starsze pokolenie. Na początku lat dwudziestych w Świeciu w składzie komisji dopuszczającej filmy większość miały starsze panie, które przemogły zakaz wyświetlania obrazu pt. Wolna miłość. Jako że film miał zezwolenie państwowej cenzury i wyświetlany był już $\mathrm{w}$ innych ośrodkach, komisja przekroczyła swe uprawnienia, co spowodowało interwencję starosty i władz wojewódzkich ${ }^{70}$. Tego rodzaju incydenty nie mogły jednak zahamować ekspansji filmu i kinematografii, który nastąpił w latach dwudziestych i trzydziestych. Liczba kin, mimo rozpoczętego jesienią 1929 r. kryzysu, rosła, choć niektóre okazywały się przedsięwzięciami efemerycznymi. Ogólne trudności gospodarcze nie wpływały na rentowność tego typu zakładów. Przykładowo w 1930 r. Hugo Gandrass, w związku z perturbacjami związanymi z koniecznością modernizacji kina „Igrzyska Świetlne”, zatrudniającego 14 osób, zrezygnował z jego osobistego prowadzenia i oddał w dzierżawę toruńskim przedsiębiorcom kinowym Ignacemu Kochowi i Józefowi Stwiecowi. Miesięczny czynsz za wynajem sali opiewał na niemałą w czasach wielkiego kryzysu kwotę 1200 złotych w złocie ${ }^{71}$. Świadczy to o dużej intratności, a co za tym idzie popularności, jakimi cieszyły się seanse filmowe. W latach trzydziestych kina istniały $w$ niemal wszystkich miastach powiatowych ( $\mathrm{z}$ wyjątkiem Tucholi), a także w mniejszych miejscowościach (Chełmży, Czersku, Golubiu, Pucku) ${ }^{72}$. W niektórych $\mathrm{z}$ pomorskich miasteczek funkcjonowało jednocześnie kilka iluzjonów (w Chełmży w roku 1930 działało ich aż cztery, w Golubiu dwa) ${ }^{73}$. Rywalizacja o klienta nie zawsze bywała uczciwa. W Chełmży za namową syna właściciela kina „Apollo" młodociany przestępca zdewastował wnętrze konkurencyjnego iluzjonu „Polonia”, a sprawa znalazła swoje rozstrzygnięcie w sądzie ${ }^{74}$. Wspólnota branżowych interesów powodowała jednak, że przedsiębiorcy kinowi wiązali się w stowarzyszenia. Niektórzy z pomorskich „kiniarzy” byli posiadaczami obiektów w kilku miastach, np. Paweł Krzyżewski z Brodnicy prowadził iluzjony w swym rodzinnym

${ }^{69}$ Łucja Kitzner-KęDZIerska, Wspomnienia, [in:] Szkolne pokolenia. Rys historyczno-wspomnieniowy, red. Aleksander CzARnecki, Wąbrzeźno 2006, s. 34.

${ }^{70}$ APB, UWP, sygn. 5020, komisaryczny starosta w Świeciu do wojewody pomorskiego, 14 XII $1920 \mathrm{r}$.

${ }^{71}$ Ibid., sygn. 5048, k. 105, kontrakt dzierżawny między H. Gandrassem a I. Kochem i J. Stwiecem, 3 III $1930 \mathrm{r}$.

${ }^{72} \mathrm{~W}$ latach trzydziestych XX w. na terenie województwa pomorskiego w granicach sprzed kwietnia 1938 r. funkcjonowało około 35 kin stałych (według danych z lat 1930-1934; z 1935 r. - 36); dla porównania w tym samym czasie na obszarze całego kraju działało (stan z 1938 r.) 807 tego typu zakładów, por. ibid., sygn. 5072, kina stałe działające na terenie województwa pomorskiego w 1935 r.; Księga Adresowa Polski (wraz z W.M. Gdańskiem) dla przemysłu, rzemiosł i rolnictwa 1930, Warszawa 1930, s. 1125-1221; Zarys historii Polski w liczbach. Społeczeństwo i gospodarka, red. Franciszek KubiczeK, Warszawa 2012, s. 271.

${ }^{73}$ Księga Adresowa Polski (wraz z W.M. Gdańskiem), s. 1125, 1129-1130, 1132, 1134, 1137, 1139, 1141, 1149, 1158, 1163, 1169, 1190, 1199, 1205-1206, 1213,1221.

${ }^{74}$ Bolesław Sprengel, Posterunek ostatniej szansy. Policja Państwowa i przestępczość w Chełmży w latach 1920-1939, Toruń 2007, s. 88-89. 
mieście oraz w Lubawie, Nowym Mieście, Działdowie i Chojnicach ${ }^{75}$. W czasie kryzysu wielu pozbawionych posady właścicieli sprzętu kinematograficznego z terenu Pomorza i województw ościennych składało także podania do Urzędu Wojewódzkiego w Toruniu o zgodę na organizowanie seansów na zasadzie kin objazdowych. Wielu z petentów uzyskiwało tego rodzaju zezwolenia, co wpływało na upowszechnienie kinematografii w mniejszych miejscowościach Pomorza. Popularność tej rozrywki sprawiała, że na Pomorzu, regionie charakteryzującym się już od końca XIX w. wysokim wskaźnikiem czytelnictwa prasy, podjęto próby wydawania periodyków dotyczących spraw kina i filmu. Pierwsze z tego typu pism, noszące tytuł „Teatr, Sztuka, Ekran”, było rodzajem przewodnika po wydarzeniach kulturalnych i rozrywkowych, gdzie obok raczej skąpych wiadomości o wyświetlanych filmach podawano także dane dotyczące repertuaru teatralnego i kabaretowego ${ }^{76}$. Czasopismem poświęconym wyłącznie sztuce filmowej i przekazującym informacje o życiu kina i jego gwiazd (zarówno zagranicznych, jak i polskich) był wydawany przez Zakłady Graficzne Wiktora Kulerskiego w Grudziądzu „Świat Filmu”77. Obie inicjatywy okazały się jednak efemerydami wydawniczymi, których żywot zakończył się zaledwie po kilku lub kilkunastu (jak w przypadku „Świata Filmu”) wydrukowanych numerach ${ }^{78}$. O premierach filmowych, repertuarze poszczególnych kin donosiły jednak na bieżąco pisma codzienne, w których specjalna rubryka w części informacyjnej zarezerwowana była dla programu lokalnych iluzjonów. W popularnym „Słowie Pomorskim” na przełomie lat dwudziestych i trzydziestych regularnie ukazywał się dział noszący tytuł „Widowiska świetlne” poświęcony aktualnościom filmowym, w którym znajdowały się recenzje obrazów i krótkie informacje o ich twórcach ${ }^{79}$. Właściciele kin, chcąc przyciągnąć amatorów sztuki filmowej, wydawali także specjalne informatory $\mathrm{z}$ zapowiedziami najważniejszych produkcji sezonu ${ }^{80}$. Na łamach prasy regionalnej nierzadko pojawiały się również informacje o życiu gwiazd srebrnego ekranu i ciekawostki o planowanych lub wyświetlanych w kinach produkcjach filmowych. Redakcje gazet odpowiadały więc na zapotrzebowanie czytelników związane z zaspokojeniem ciekawości związanej $\mathrm{z}$ ulubioną formą rozrywki. Wyjście do kina stało się bowiem w okresie międzywo-

\footnotetext{
${ }^{75}$ APB, UWP, sygn. 5044, kina stałe działające na terenie województwa pomorskiego w 1935 r.; E. BRZESKA, op.cit., s. 229; Szczepan WIERzCHOSŁAWSKI, Brodnica w okresie międzywojennym (1920-1939), [in:] Brodnica. Siedem wieków miasta, red. Jerzy DygdaŁA, Brodnica 1998, s. 45; H. RzĄSKA, op.cit., s. 123.

${ }^{76}$ Zob. np. Teatr, Sztuka, Ekran. Pismo ilustrowane, poświęcone sprawom teatru, muzyki, sztuki, kinematografu wraz z programem widowisk na cały tydzień, nr 6 z 25 V 1924 r.

${ }^{77}$ Zob. np. Świat Filmu. Dwutygodnik poświęcony dziedzinie kina. Grudziądz, Warszawa, Poznań, Bydgoszcz, Toruń, Łódź, Kraków i inne miasta, R. 2: 1933, nr 1.

${ }^{78}$ Wiktor Pepliński, Prasa pomorska w Drugiej Rzeczypospolitej 1920-1939. System funkcjonowania i oblicze społeczno-polityczne prasy polskiej, Gdańsk 1987, s. 87, 144.

${ }^{79}$ Por. np. Widowiska świetlne, Słowo Pomorskie, nr 260 z 10 XI 1929 r.; Widowiska świetlne, ibid., nr 113 z 16 V 1930 r.; Widowiska świetlne, ibid., nr 25 z 31 I 1931 r.

${ }^{80}$ Por. Dla miłośników kina. Informator Kino-Teatru „Palace” w Toruniu, Toruń [1928]. Na sezon 1928/1929 przewidywano wyświetlenie 77 obrazów.
} 
jennym, także w prowincjonalnych miastach Pomorza Nadwiślańskiego, jednym ze stałych elementów codzienności. O tym, jak bardzo ugruntowane było to przyzwyczajenie, donosił nawet potępiający oddziaływanie kina na mentalność widzów „Miesięcznik Diecezji Chełmińskiej”. Na kartach tego katolickiego przewodnika postulowano jednak oglądanie filmów odpowiednich i moralnych. Całkowity zakaz uczestnictwa w przedstawieniach ruchomych obrazów nie wchodził już bowiem w rachubę, ,gdyż dziś ludność niełatwo z tych przyjemności widowiskowych zrezygnuje" - puentował swe wywody na początku lat trzydziestych autor artykułu ksiądz kuratus Franciszek Czapliński ${ }^{81}$. Pozytywne strony uczestnictwa w seansach filmowych dostrzegał także pierwszy burmistrz Gdyni Augustyn Krause, zgłaszając w 1926 r. postulat uruchomienia iluzjonu w powstającym od podstaw mieście. Kino bowiem miało odciągnąć osiedlających się w nowym polskim mieście portowym ludzi różnej konduity społecznej od „pijaństwa i hultajstwa”82. Uczestnictwo w seansach filmowych przełamywało także sztywne dotąd bariery społeczne. Stało się ono rozrywką egalitarną, na którą stać było nawet gimnazjalistów czy słuchaczy szkół wojskowych ${ }^{83}$. Kino nie było bowiem przeznaczone wyłącznie dla elit i podobnie jak sport należało do rozrywek z jednej strony wyjątkowo tanich, a z drugiej oddziałujących w sposób intensywny na emocje i uczucia. Dobrą ilustracją ówczesnego fenomenu jest fragment wspomnień pomorskiej pisarki Anny Łajming, w którym przedstawiła wizytę $\mathrm{w}$ jednym $\mathrm{z}$ tczewskich kin około połowy lat trzydziestych: „Był post, ale męża ciągnęło choćby do kina, tym bardziej że grano jakąś amerykańską komedię i chciał się pośmiać. Ja wolałam filmy poważne i konkretne. Nie znosiłam na przykład «Pata i Patachona». [...] [mąż] w kinie na «Flipie i Flapie» po prostu ryczał ze śmiechu. [...] W tę niedzielę choć padał śnieg $\mathrm{z}$ deszczem do kina jednak wybraliśmy się. [...] Tam, w mroku, w pierwszym rzędzie zobaczyłam, jakąś panią $\mathrm{z}$ dziewczynką. [...] Była to guwernantka z małoletnią hrabianką, Izabelą Łubieńską. [...] Podczas wyświetlania filmu z Patem i Patachonem bez przerwy myślałam o małej Izetce, zazdroszcząc jej dzieciństwa w zbytku i urody" ${ }^{\text {"4. }}$.

Sztuka kinematograficzna w niebywale szybki sposób zdobyła uznanie wśród mieszkańców Pomorza Nadwiślańskiego. Liczba kin stałych oraz objazdowych, które rozpoczęły i kontynuowały działalność w pierwszym czterdziestoleciu XX w., gwarantowała powszechność odbioru nowego medium, co było zresztą jego cechą charakterystyczną. Film, po prasie, a niemal równocześnie z radiem, stał się bowiem środkiem masowego przekazu, za pomocą którego transmitowane były informacje, idee i wzorce kulturowe. Fenomenowi temu sprzyjały zmienne i bardzo dynamiczne fluktuacje uwarunkowań politycznych. Pośrednio dzięki tym okolicznościom film i kinematografia $\mathrm{z}$ odpustowej ciekawostki przeobraziły

\footnotetext{
${ }^{81}$ F. CZAPLIŃsKI, op.cit., s. 347.

${ }^{82}$ Stanisław Zieliński, Pierwsze gdyńskie kina, Rocznik Gdyński, nr 6: 1985, s. 218; P. ŚliwińSKA, op.cit., s. 86.

${ }_{83}^{83}$ Wiesław Mirecki, Malowane dzieci. Wspomnienia ułana, Warszawa 1986, s. 214.

${ }^{84}$ Anna Łajming, Mój dom. Wspomnienia, Gdańsk 1997, s. 47.
} 
się $\mathrm{w}$ jeden $\mathrm{z}$ najistotniejszych czynników kultury masowej i komunikacji społecznej. Specyfika Pomorza, jako obszaru współwystępowania, a od połowy XIX stulecia także pogłębiającej się rywalizacji między kulturą niemiecką i polską ${ }^{85}$, oraz zmiany polityczne i społeczne, jakie przyniosła pierwsza wojna światowa i jej wielkie następstwa ${ }^{86}$, odcisnęły piętno także na rozwoju sieci tutejszych kin oraz odbiorze nowej formy sztuki i spędzania wolnego czasu. Początkowa dominacja filmów niemieckich, co było oczywiste ze względu na sytuację polityczną i gospodarczą oraz uwarunkowania kulturowe, po wielkiej wojnie ustąpiła wpływom masowej produkcji amerykańskiej, a także coraz bardziej dostrzegalnej i cieszącej się popularnością filmografii polskiej ${ }^{87}$. Produkcje niemieckie traktowane jeszcze na początku lat dwudziestych neutralnie lub nawet przychylnie pod koniec omawianego okresu były już otwarcie bojkotowane. Początkowo seanse świetlne były rozrywką nisko ocenianą, porównywaną do przedstawień cyrkowych. Negatywnie na jej temat wypowiadały się elity oraz władze kościelne. W ciągu zaledwie trzech dziesięcioleci rozrywka ta przybrała formę najbardziej chyba masowego uczestnictwa w kulturze. Film stał się faktem społecznym i kulturowym silnie powiązanym $\mathrm{z}$ dotychczasową kulturą literackąa ${ }^{88}$. Ewolucja ta przyczyniła się do zmiany postrzegania filmu zarówno przez zwykłych odbiorców, jak i ludzi władzy szczebla regionalnego i lokalnego, tym bardziej że świadkowie narodzin i pierwszych dziesięcioleci kina uczestniczyli w przemianach konwencji i poetyki ówczesnego kina, czego najbardziej znaczącym symbolem stało się udźwiękowienie filmu. Pomorska „soczewka” pozwala obserwować te zjawiska z perspektywy lokalnej, dzięki czemu dostrzec można pewne przemiany społeczne i mentalnościowe mieszkańców ziem pomorskich wynikłe i ściśle związane z procesami historycznymi toczącymi się w tamtych czasach.

dr Tomasz Krzemiński

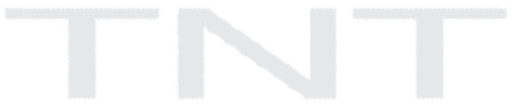

Instytut Historii PAN

e-mail: tomasz_krzeminski@interia.pl

${ }^{85}$ Por. Szczepan WierzchosŁawski, Wrogość czy koegzystencja? Codzienne relacje Polaków i Niemców na Pomorzu Nadwiślańskim przed pierwsza wojna światowa (zarys problematyki), Czasy Nowożytne, t. 26: 2013, s. 124; Cezary Oвracht-Prondzyński, Pomorska wielokulturowość: niewykorzystane potencjały czy potencjalne ryzyka, [in:] Pomorska debata o kulturze: kultura na pograniczu - pogranicza kultury, red. Cezary OвRAснт-Prondzyński, Katarzyna Kulıkowska, Gdańsk 2014, s. $34-45$.

${ }^{86}$ Por. Paweł Kosı́́ski, Prusy Zachodnie 1914 - Pomorze 1920. Ludność regionu wobec przemian politycznych okresu I wojny światowej, Warszawa 2002.

${ }^{87}$ S. ZIELIŃsKI, op.cit., s. 219-220.

${ }^{88}$ Maryla Hopfinger, Komunikacja filmowa lat dwudziestych i trzydziestych w Polsce wobec kultury literackiej, [in:] Polskie kino lat 1918-1939 (zagadnienia wybrane), red. Zbigniew WyszyŃski, Kraków 1980, s. 21. 


\section{DIE GESELLSCHAFTLICHE AUFNAHME DER KINEMATOGRAFIE IN WEICHSELPOMMERN ZU BEGINN DES 20. JAHRHUNDERTS}

\section{Zusammenfassung}

Schlüsselwörter: Alltagsleben, Westpreußen, Wojewodschaft Pommern, Unterhaltung, Teilnahme an Kultur, Mediengeschichte, Kino, Mentalität, Brauchtum, Freizeit

Kinovorführungen gab es in Weichselpommern schon wenige Monate nach der Pariser Premiere der Erfindung der Brüder Lumière. Am Beginn des 20. Jahrhunderts waren die Vorstellungen, die zuerst durch Wanderkinos organisiert wurden, schon sehr populär, sowohl in größeren wie in kleineren Städten der Region. Die Faszination des neuen Mediums ergriff die Bevölkerung unabhängig von der ethnischen Spaltung unter den Einwohnern des Gebiets. Der 1. Weltkrieg brachte eine wachsende Ideologisierung der Kinematographie; es verschärften sich auch die Formen staatlicher Kontrolle über die Inhalte, die über die Leinwände vermittelt wurden. In der Zeit zwischen den Weltkriegen wurde auch das Kino ein Element der kulturellen Rivalität zwischen Polen und Deutschen. Die Verbreitung und die Popularität des Films sowie die Flut amerikanischer Streifen führten zu Veränderungen in den Sitten und der Mentalität der Bevölkerung der Wojewodschaft Pommern zwischen den Kriegen.

\section{THE SOCIAL RECEPTION OF CINEMATOGRAPHY IN POMERELIA AT THE BEGINNING OF THE $20^{\text {TH }}$ CENTURY \\ Summary}

Key words: everyday life, Western Prussia, the Pomeranian voivodeship, entertainment, participation in culture, the history of the media, cinema, mentality, customs, free time

Cinematographic shows were held in Pomerelia several months after the invention of the Lumiere brothers had been presented for the first time in Paris. At the beginning of the 20th century such shows, originally organised as touring forms of entertainment, were very popular both in the major and smaller towns of the region. The fascination with the new medium affected the whole population irrespective of the ethnic origin of the inhabitants of the region. WW I resulted in an increased ideologisation of cinematography; the forms of state control over the content of films became stricter. In the interwar period, cinematography became an element of cultural competition between Poland and Germany. The prevalence and popularity of film along with the influx of American images influenced the morality and mentality of people living in the Pomeranian voiodeship in the interwar period. 